\title{
It's Never too Late to Mend: Potentials of CLIL Pedagogical Approach to Internationalize Ethiopian Journalism Education
}

\author{
Shafaat Hussain \\ Department of Journalism and Communication, Madda Walabu University, Bale-Robe, Ethiopia \\ Email: shafaa thussain6@gmail.com
}

How to cite this paper: Hussain, S. (2019). It's Never too Late to Mend: Potentials of CLIL Pedagogical Approach to Internationalize Ethiopian Journalism Education. Creative Education, 10, 2246-2269. https://doi.org/10.4236/ce.2019.1010162

Received: September 9, 2019

Accepted: October 26, 2019

Published: October 29, 2019

Copyright (อ 2019 by author(s) and Scientific Research Publishing Inc. This work is licensed under the Creative Commons Attribution International License (CC BY 4.0).

http://creativecommons.org/licenses/by/4.0/

Open Access

\begin{abstract}
Recently, due to globalization and the consequent knowledge sharing, there is a paradigm shift in the focus of education. English is a new wave flowing throughout the academic landscape of the world. 21st century is facing the challenges of the new status of English language as a lingua franca. Globally, many countries have embraced English as a medium of instruction to prosper in this new world economic order. This is impacting the didactics and pedagogy in the educational systems as a consequence of which fresh winds of pedagogic changes are blowing and new approaches are knocking. Furthermore, innovative curriculums are appearing and equally rejuvenated materials are coming up. More interactive classrooms are becoming the predominant feature of the contemporary pedagogical practice. Besides, the new technologies, the multimodal ways, growing local diversity and global connectedness are calling for an educational response to the expectations of the modern age. Today, learning is moved from the acquisition of knowledge to the development of the competence, expertise and problem solution. This article contextualizes the Content and Language Integrated Learning (CLIL) approach to journalism education in Ethiopia. This article begins with the conceptualization of CLIL, and justifies why CLIL is necessary for journalism education in Ethiopia. The article further signifies how CLIL philosophy is beneficial for journalism education; and how CLIL approach can be used as a journalism educational approach. In addition, the article argues how CLIL can be contextualized for curriculum design, material development, and classroom procedure of journalism education. The article concludes that if CLIL approach is used as journalism pedagogic approach, there is a greater chance of better curriculum design, enhanced material development, and discourse-oriented classroom procedures. This will certainly lead to the academic success and professional achievement of both the learners and the teachers.
\end{abstract}




\section{Keywords}

CLIL, Journalism Education, Journalism Curriculum, Journalism Material, Journalism Classroom

\section{Introduction}

The issue of English language incompetence among the Ethiopian undergraduate students is a usual discussion among instructors, educationists and industrialists (Hailom, 1982; Berhanu, 1999; Lakachew, 2003; Yonas, 2003; Yemene, 2007). This issue, which is not only an issue of Ethiopia, has been attempted to address in the different multilingual parts of the world through an advanced communicative language teaching (CLT) approach called "content and language integrated learning” (CLIL). CLIL approach is emerged from American Contentbased approach and Canadian immersion program (Khan \& Pinyana, 2014) in the field of English as a specific purpose (ESP). The term CLIL coined by David Marsh in 1994, is an educational approach to teach subject contents in a foreign language (FL) with the language skill development, subject matter competence and pedagogical innovations (Marsh, 2002; Wolff, 2009). CLIL is also termed as "an umbrella of dual focus" (Mehisto, Marsh, \& Frigols, 2008; Kiely, 2009; Coyle, Hood, \& Marsh, 2010), and "innovative, modern, effective, efficient and forward-looking" (Coyle et al, 2010; Dalton-Puffer, Nikula, \& Smit, 2010) approach. As a learner of both Teaching English as a Foreign Language (TEFL) and Journalism and Communication, the researcher has visualized immense possibilities within CLIL to solve current pedagogic problems in journalism undergraduate program.

\subsection{Conceptualizing "CLIL"}

CLIL refers to situations where subjects or parts of subjects are taught through a foreign language with dual-focused aims, namely the learning of content and the simultaneous learning of a foreign language (Marsh, 2002). It involves teaching a curricular subject through the medium of a foreign language (Klimova, 2012). CLIL is argued to be a modern tool of mobility, employability, and multicultural awareness. Although learning through the medium of a second or additional language has existed for many centuries, the origin of the acronym CLIL was coined in Europe in the early nineties (Coyle et al., 2010). It is widely adopted at policy level that is, "mother tongue plus two other languages" (MT +2$)$ and running in full swing throughout the European continent. After successful gains in Europe, CLIL moved to Latin American countries in the 19th century (Banegas, 2011) and came up with flying colors there too. In South East Asia, CLIL is being used at academic institutions for the sake of English medium instructions (EMI).

\subsection{Variants of CLIL}

CLIL has diverse realizations and it ranges from total immersion and bilingual 
education to lesson thematization. It is an overarching, wide and all-encompassing in scope that covers all possible combinations and varieties of content and language learning (Coyle et al., 2010; Costa \& D’Angelo, 2011; Banegas, 2011). Lucietto (2008) suggests three CLIL variants: 1) Learning the FL separately, in order to learn the content through the FL; 2) Learning the FL through the content, which has already been learnt in the L1; and finally 3) Learning the FL and the content together. It may be argued that the viewpoints in favor of CLIL generally suggest the last option, that is, the content and FL learning go hand-in-hand (Bruton, 2013). Massler, Stotz, \& Queisser (2014) suggest three forms of CLIL. In type A, learning aims are based on the content of the academic subject taught through the medium of a FL and assessment is mainly based on content. In type $\mathrm{B}$, programs in which FL instruction is thematically based and content from other school subjects are used in the language class. In this case the aims and assessment focus on the FL. In type $\mathrm{C}$, a full integration of content and language "shown in the pupils' timetable as a subject of its own", but this is a "rare phenomenon". Claudiocol (2010) argues that there are three kinds of CLIL: hard, mid and soft CLIL. Hard CLIL is the way through which half of the curriculum is taught in the target language focusing more on content (content-led). Mid CLIL is the way in which a subject is taught for a limited number of hours in both the target language and first language (L1). Soft CLIL is the language led course curriculum, (focusing on language) in which the learners are taught by using different content subjects such as biology, physics, chemistry, etc. Further, according to English Teachers Federation of Argentina in Spanish (FAAPI, 2008), the content and language integration is of two broad types: 1) the inclusion of curricular content into the EFL class and 2) the teaching of a curricular subject in English (Banegas, 2011). Therefore, the suitable variant of CLIL in Ethiopian journalism undergraduate context is the $\mathrm{FL}$ and the content together suggested by Bruton (2013), the content of the academic subject taught through the medium of a FL (type A) suggested by Massler, Stotz, \& Queisser (2014), content-led hard CLIL suggested by Claudiocol (2010), and the teaching of a curricular subject in English FAAPI, 2008 as suggested by Banegas (2011).

\subsection{Core Focus of CLIL}

The core focus of CLIL is linked to culture, environment, language, content and learning. Firstly, CLIL has been identified as one way to achieve positive results in intercultural knowledge and understanding. Transforming knowledge into understanding often needs to be realized through experimental methods. Intercultural knowledge and understanding help develop intercultural skills. The aspect of wider cultural context can be used to facilitate such process of cultural/linguistic adaption (Marsh, 2002). Secondly, CLIL is used as a unifying platform to make students linguistically and content-wise prepared to take up their rights in this era of globalization and internationalization. Many opportunities for scholarship and further education funding are available for young graduates 
and CLIL could be used for such preparations for learners (Marsh, 2002). Thirdly, improving overall language competence has been the basic focus of CLIL. All four language skills are developed through CLIL. A student may have the knowledge of a language but it does not mean that the student is able to use the language skills in real-life situations. Many CLIL studies have reported that it helps improve learners' communicative language skills without which their academic achievements and professional success are impossible. CLIL deepens awareness of both L1 and L2. The fourth focus of CLIL is content. CLIL provides opportunities to study content from different perspectives. For example, journalism is sometimes seen differently depending on the country and its culture. Therefore, educational curricula of different countries are not identical on the same matter. These different world-views can be seen in the ways in which some content is taught. However, it may lead to significantly diverse ways of approaching and understanding similar phenomena. CLIL enables learners to study through these different perspectives, which can lead to achieving a deeper understanding of the subject matter. Also, CLIL helps learners understand the subjects and their core terminology in the target language. The final focus of CLIL that has been pointed out is learning. Special emphasis is on learner-based methodologies to improve learning by paying attention to individuals' needs in terms of social and analytical skills. Therefore, individual learning strategies are improved through CLIL. Also, CLIL helps develop students' analytic, reflective and hypothesizing skills and all that encourages them to become much greater risk-takers in terms of their linguistic self-confidence. The main characteristic of many CLIL methodologies is the synergy resulting from communication orientation on the language, the content, and the interaction as it takes place within classroom. It is stated that this approach is much more effective than traditional EMI teaching. CLIL programs are often focused on providing non-threatening and supportive contexts where most or all learners feel comfortable with the classroom objectives. The whole process is relaxed and natural. Therefore, CLIL helps increase learner motivation.

\section{Theoretical Underpinnings to CLIL}

The theoretical justification of CLIL is deeply rooted in second language acquisition (SLA) theories-the input hypothesis, the interaction hypothesis, the output hypothesis, the basic interpersonal communication skills, the cognitive academic language proficiency, and the common underlying language proficiency. In contexts of instruction, Krashen's Input hypothesis. $I+1$ (Krashen, 1982) postulates that language is acquired incidentally when the learner is exposed to comprehensible L2 input (Grabe \& Stoller, 1997). Current research in SLA indicates that a critical element in effective instruction is access to comprehensible input in target language. One way to provide comprehensible input directly to a student is by teaching content in English using strategies and techniques that make the content comprehensible to the learner who is learning in second language 
learner (Krashen \& Biber, 1988; McDougald, 2009). Swain's $(1985,1993)$ output hypothesis assumes that learning depends on explicit attention to productive skills and focuses on relevant and contextually appropriate language forms to support content-learning activities in the classroom (Grabe \& Stoller, 1997). Cummins Basic Interpersonal Communication Skills (BICS, 1984) refers to the ability to comprehend and respond to conversational language. It describes social, conversational language used for oral communication. Also described as social language, this type of communication offers many cues to the listener and is context-embedded language (Castillo, 2008). BICS refers to a basic language skill, normally acquired through formal teaching, which is necessary for interacting in normal everyday situations. It is composed of automated communicative tasks that do not require much cognitive ability (Costa \& D'Angelo, 2011).

Cummins Cognitive Academic Language Proficiency $(C A L P, 1984)$ is the context-reduced language of the academic classroom. It takes five to seven years for English language learners to become proficient in the language of the classroom. Learners who are proficient in social situations may not be prepared for the academic, context-reduced, and literacy demands of mainstream classrooms. Students need to develop CALP if they are to succeed in academic L2 learning contexts (Grabe \& Stoller, 1997; Castillo, 2008). It is the linguistic competence strictly connected to context. Though entailing a low cognitive skill, BICS is very closely linked to an everyday context, while CALP is highly demanding, cognitively speaking, though characterized by a low everyday context. Cummins emphasizes that these two competences are not independent and can, therefore, be acquired simultaneously (Costa \& D'Angelo, 2011). Cummins Common Underlying Language Proficiency (CULP, 1984) provides the base for the development of both the L1 and the L2. It follows that any expansion of CULP that takes place in one language will have a beneficial effect on the other language(s). Regardless of the language in which a person is operating, the thoughts that accompany talking, reading, writing, and listening come from the same central processing system or the source of thought. People can function in two or more languages with relative ease. Information processing skills and educational attainment may be developed through two languages as well as through one language. Cognitive functioning and school achievement may be fed through one monolingual channel or equally successfully through two well-developed language channels. Both channels feed the same central processor (Cummins, 1984; Shoebottom, 2000; Wagner, 1990; Castillo, 2008).

\section{Conceptual Framework}

Ethiopian journalism undergraduates lack in English skills (listening, reading, speaking and writing) and subject-matter competences are a well-known problem. This review aims at creating an interface between TEFL and journalism undergraduate pedagogy for enhancing learners' language skills and content competences through discourse-oriented curriculum, material and classroom. 
The researcher has attempted to contextualize the potentials of CLIL approach and its principles to develop a pedagogical model of teaching journalism. Therefore, this study fills four gaps in journalism undergraduate program by introducing CLIL philosophy: cognitivism and constructivism in journalism educational philosophy; CLIL approach in journalism TL process; CLIL design in journalism curriculum design and material development; and CLIL procedure in journalism classroom technique (Figure 1).

The conceptual framework clearly portrays that by contextualizing CLIL philosophy, approach, design and procedure with that of journalism, there is a high possibility of language and subject matter competence and the consequent academic achievement among journalism undergraduates. Although there has been extensive research conducted on CLIL approach, especially in Europe (Cañado, 2010; Costa \& Coleman, 2010; Lasagabaster \& de Zarobe, 2010; Navés \& Victori, 2010; Smit, 2010a, 2010b; Bolton \& Kuttiva, 2012; Nikula \& Järvinen, 2012; Pérez-Cañado, 2012; Saarinen, 2012; Smit \& Dafouz, 2012; Dafouz-Milne \& Sanchez-Gracia, 2013; Fortanet-Gómez, 2013; Williams, Strubell, \& Williams, 2013; Khan \& Pinyana, 2014) and other continents too but it hasn't yet knocked the Ethiopian threshold so far. This study is a brain child of the researchers' 10 years hunting of a suitable approach for journalism undergraduate pedagogy in Ethiopia. During these years of my teaching in two universities, I realized

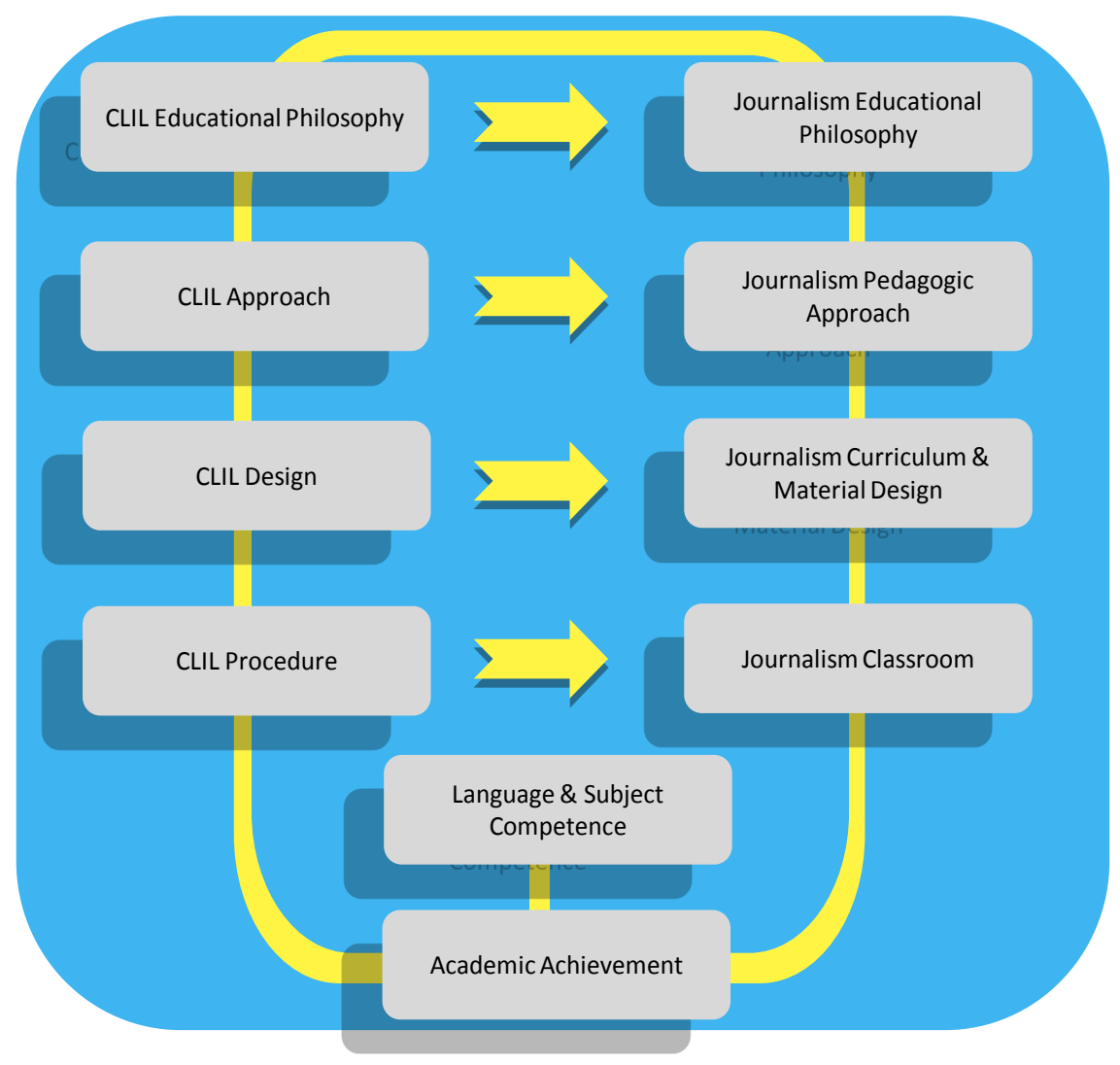

Figure 1. Contextualizing CLIL to journalism education: A conceptual framework. 
that both teachers and students are struggling with the serious problem of content and language disequilibrium. The teachers have to teach content with learners' poor English skills and subject competences and the learners have to struggle for academic achievements with their poor English skills and subject competences. To solve this, in the following sections, attempts are made to contextualize CLIL philosophy, approach, design and techniques with that of journalism undergraduate pedagogical approach.

\section{Journalism Education in Ethiopia}

The first Ethiopian university (Addis Ababa University) was instituted in 1950. Later in 1954, the second university (Haramaya University) was established in Ethiopia. There were only seven universities in Ethiopia till 2007; however, by the year 2012, the number tremendously increased to 34. At present, there are 64 accredited non-government universities and colleges, which grant undergraduate degrees in Ethiopia (Universities and colleges..., 2018). The journalism education in Ethiopia got its formal beginning in the year 1996 when Ethiopian Mass Media Training Institution (EMMTI) was founded in Addis Ababa. In 2003, EMMTI was undertaken by Addis Ababa University. The first initiative in private sector was taken by Unity University College, Addis Ababa where diploma in journalism was introduced in 1998 followed by undergraduate journalism degree programme in 2000. Although Ethiopia was late riser in journalism education among East African nations, yet it is mushrooming fast after consolidation of second-generation universities. Presently out of 34 universities, 14 universities are running journalism and communication programmes. At present, the Ethiopian media market consists of one federal radio and television, six public and 19 private newspapers, $10 \mathrm{FMs}, 25$ radio stations, and 58 private media channels (IMS, 2018). Ethiopian government wants to fulfill the demands of qualified journalists through outstanding journalism education in the universities. However, the educational approaches for the fast-burgeoning journalism programs are not yet well studied and discussed.

\section{Justification of CLIL for Journalism Education}

This study presents obvious rationale why CLIL should be adopted as an approach to journalism undergraduate pedagogy for Ethiopian universities. Foremost, CLIL proposes a sound theoretical and methodological approach which blends both competences: FL skills (English) and subject matter (journalism) simultaneously. This approach is guided by two philosophies: cognitivism and constructivism (Wolff, 2009). The cognitivism believes that language is learned through conversation and interaction which can be achieved by comprehensive inputs and their modifications (Krashen, 1982; Long, 1983; Hatch, 1992; Pica, 1994; Platt \& Brooks, 2002). The constructivism postulates language learning as a tool of gaining knowledge i.e., language + content = knowledge; and knowledge is a combination of both declarative (factual) and procedural (dealing) 
competence (Strohner, 1995; Wolff, 2009). Both philosophies are the soul of journalism teaching and learning. Second, although English as a foreign language (EFL) is "across the curriculum" in all content subjects at university level but a program like journalism is very unique in the sense that it is not taught in schools. Therefore, the learners deal with the maiden and varied content they never encountered before. Adopting CLIL is a natural choice for a discipline like journalism. Third, university entrants, in general, are linguistically weak in four skills that affect their grade achievement as a consequence of which they lack in motivation, interest, involvement, enthusiasm and curiosity. Emphasis over EFL skill development through CLIL can make their learning better, easier and faster. Fourth, CLIL is not a high-tech idea that cannot be implemented in Ethiopian context. As a matter of fact, it is a policy decision which can go with the available scarce resources. Fifth, employers always complain that universities are not producing competent and state-of-the-art journalists. Emphasis over innovative pedagogy; higher order conceptual and critical thinking activities; cognitively and conceptually challenging tasks; and process-oriented assessment techniques through CLIL can bring change. It goes without saying that learning is maximized if learners use language with the content involvement. Lastly, exposure to FL outside the classroom is scarce in Ethiopian context which justifies the need for linguistic scaffolding to the journalism undergraduates. The good thing is that language teaching is not allowed in CLIL classes but the didactics is centered on content thrived interactions. The CLIL approach has already been introduced into Higher Education in European universities through European Space of Higher Education (ESHE), Latin American and South East Asian countries to meet the needs of rapid internationalization. At tertiary level, English is a medium of instruction automatically correlate with the introduction of CLIL and it can be a professional development catalyst (Coyle et al., 2010).

There are many other reasons why CLIL should be contextualized in Ethiopian journalism undergraduate pedagogy: One, the whole teaching-learning (TL) principle and process is silent about any philosophy, approach, design and techniques for teaching journalism. As TL English in Ethiopia is adhered to CLT approach, a program like journalism has no approach at hand. Two, the subject/course like journalism is taught through an additional language, that is, English. Journalism is a non-linguistic academic professional discipline. Here, language is not focused rather content matters in TL and language skills supposed to come automatically. All teaching and learning activities and assessments are in English. The learners encounter language while they are learning the subject. Hence, CLIL and journalism undergraduate pedagogy fit together. Three, although EFL is inherent and "across the curriculum" in all content subjects of the universities but a program like journalism especially falls into this category as it is not taught in schools and therefore, the learners have to deal with the varied content subject they have never encountered before. Adopting CLIL is a natural choice for them because of the nature of the program. Four, 
CLIL addresses the linguistic demands of content learning. CLIL acts as a bridge to help student boost their skills of English through the study of contents (Banegas, 2011). We are in the age of internationalization and English is a lingua franca of this globalised world. Students are facing dual challenges simultaneously: mastery over contents and language skill acquisition. CLIL proposes the ultimate communicative methodology (Graddol, 2006) with dual focus: language and content (Mehisto, Marsh, \& Frigols, 2008; Kiely, 2009; Coyle et al., 2010). Six years' experience and close observation of researcher in two Ethiopian universities have revealed that in writing, learners lack in vocabulary, spelling and sentence formation. In speaking, they starve for words, string wrong sentences and pronounce incorrectly. In reading, there is no culture of reading among journalism students. If there is reading, it is only limited up to handout. In listening, there is an absence of practical listening or watching authentic materials of journalism and communication. Five, CLIL is more motivating in nature (Banegas, 2011). Learners feel more motivated within CLIL which enables higher achievements and outcomes in their learning process (Spies, 2012). University undergraduate, in general, is linguistically weak to follow FL instructions that affect their grades (Hailom, 1982; Berhanu, 1999; Lakachew, 2003; Yonas 2003; Yemene, 2007) and therefore they lack in motivation, interest, involvement, enthusiasm and curiosity. Emphasis over EFL skill development through CLIL would make their learning better, easier and faster. Six, CLIL is more contextual in nature which prepares learners to communicate in a second language within a meaningful academic context (Spies, 2012; Banegas, 2011). It gives teachers an opportunity of delivery through thematic content topics inside the classroom followed by tasks to be accomplished outside the classroom. Seven, Students are having diverse language background and diverse learning abilities in undergraduate classroom. CLIL may also be justified here saying that we lack an approach wherein both content and language go hand in hand. A teacher goes with curriculum and a student with cognition. But, during cognition what a student faces are language barrier. If a teacher feels it and goes to correct language s/he lags behind in the content plus language becomes a burden on students (Jarvinen, 2008; McDougald, 2009). Eight, exposure to EFL outside the classroom is scarce in Ethiopian context which justifies the need for maximum linguistic scaffolding to the journalism undergraduates. Nine, the variety of testing and criterion of evaluation used in assessments is not specifically categorized according to the topic in the curriculum rather it is mentioned customarily and repetitively. Hence, testing is solely dependent on teacher's pedagogic ability and mostly teachers are from non-pedagogic and non-linguistic background. Through CLIL teacher's training we may overcome the issue. Ten, CLIL provides a framework where learning has moved from the acquisition of knowledge to the development of the competence and expertise that learning produces; a standpoint where the emphasis is put on problem-solving (Fernández, 2009). Media employers always complain that universities are not producing competent 
and state-of the-art journalists. Emphasis over innovative pedagogy, procedural activities, tasks and assessments in the classroom through CLIL can bring a tangible change. Final, CLIL is not a high-tech idea but an improvised version of CLT (Costa \& D'Angelo, 2011); rather, it is an approach very suitable in Ethiopian context where teaching practices usually go with the limited resources.

\section{Contextualizing CLIL Philosophy to Journalism Educational Philosophy}

Educational philosophy is a set of correlative assumptions having certain theories, method, design and technique. Some of the important philosophies of language learning are for example, behaviorism, structuralism, functionalism, nativism, cognitivism and constructivism. CLIL is backed by two prominent educational philosophies: cognitivism and constructivism (Wolff, 2009).

\subsection{Cognitivism}

"Cognitivism" is a philosophy assuming that learning a FL is an individual's mental process (Doughty \& Long, 2003) which takes place mostly in the mind (Davis, 1995). Skills and knowledge follow a general sequence of stages of learning from the cognitive stage, to the associative stage, to the autonomous stage. In the cognitive stage, students notice and attend to information in working memory; typically, they engage in solving basic problems with the language and concepts they are encountering. In the associative stage, errors are corrected; declarative and productive knowledge are strengthened and the knowledge and skills become procedural. In the autonomous stage, performance becomes automatic, requiring little attention effort, and it is well integrated within a strong network that activates additional information through spreading activation. This final stage frees up cognitive resources for the next cycle of problem-solving. It is a reasonable characterization for academic language learning and a strong learning theory for instruction which integrates attention to content and language.

Cognitivism relies heavily on scaffolding, that is, "the provision of extensive instructional supports when concepts and skills are being first introduced and the gradual reduction of supports when students begin to develop greater proficiency, skills, or knowledge". Hence, cognitivism believes that FL learning is conversational with comprehensive inputs and their modifications. The main idea behind it is that second language acquisition takes place through conversational interaction. Researchers like Hatch (1992), Long (1983) and Pica (1994) argue that what Krashen (1982) calls comprehensible input is necessary for language learning, but that in order to understand the effect interaction has on the learning process the question must be answered how input is made comprehensible. Cognitivists claim that this takes place through negotiation of meaning. Interaction involves negotiation of meaning and this entails modification of input which in turn makes the input comprehensible. So actually, what promotes acquisition is interactional modification. Later on, in the development of the 
theory, a more far-reaching argument was added (Platt \& Brooks, 2002). Through modification, it was claimed, the learner's attention is focused on a specific linguistic structure of the target language which is thus taken in and learned. There can be no doubt that these ideas constitute an interesting theoretical construct in order to understand why in a CLIL classroom language learning takes place although the learner's attention is focused on content.

\subsection{Constructivism}

"Constructivism" is a philosophy which theorizes that knowledge is not acquired but constructed (Wadsworth, 1996). Every individual has his/her own construct of reality and experience. With new input, a learner creates a mental structure (schemata/concept) through assimilation and accommodation. Learning is caused due to disequilibrium of the prior mental construct. According to constructivism, learning means constructing and not acquiring knowledge. This process of construction is governed by the structures of the learner's mental model of reality and is both autonomous as well as active. Consequently, teaching should not be understood as instruction, i.e. knowledge transmission. Rather, it should be re-conceptualized as a process which can encourage the learner's activities of constructing reality. Since the learner knows best which reconstructions are necessary and possible in his/her personal model of reality, teaching should allow learners to follow their own path of disequilibrium (Wadsworth, 1996). After all, if knowledge is imposed from outside, it is very likely that the learner will only learn the information by heart but will neither be motivated nor able to integrate it into his/her individual construct of reality. If however, learners have the opportunity to construct knowledge autonomously on the basis of their individual schemata; this knowledge can be retained and used. Thus, teaching which embraces constructivist thought gives learners the freedom to be active and autonomous in their learning (Overmann, 2002; Gefall, 2009).

Although constructivism emphasizes the importance to give learners freedom in their learning, this does not mean that constructivist leave teaching astray. Rather teachers by, for example, asking guiding questions support learners in their exploration and cause disequilibrium. The teacher shows the way if learners tend to wrong conclusions. Teachers should also find out pupils' interests and by drawing on their curiosity, initiate research and show them why certain information could be relevant to them (Wadsworth, 1996). Above all, teachers help learners to develop those learning strategies which allow active and autonomous learning (Wendt, 1996; Gefall, 2009). Apart from a teacher who aids students in their construction of knowledge, the learning environment is essential for successful learning to be possible. Only in a rich learning environment which provides many different stimuli can pupils experience disequilibrium and engage in those construction processes which are appropriate for them. Therefore, the learning environment has to provide different opportunities for construction, such as a range of different materials and tasks (Rüschoff, 1999). In 
this learning environment pupils should be allowed to choose their activities, to present the outcomes of their research and to self-evaluate their work (Wendt, 1996). Both individual and group work has to be possible (Wolff, 2007; Gefall, 2009). Moreover, this environment should not only afford rich opportunities to be mentally and physically active but it should also be authentic. Only in an authentic learning environment can pupils develop "constructs of reality" which have adaptive value outside the classroom. Consequently, pupils should be asked to solve real-world problems in an environment which allows them to find solutions appropriate for the "real-world" (Mardziah-Hayati, 1998).

In conclusion, constructivist teaching encourages learner to be active and autonomous, to develop learning strategies and real-life problem-solving skills in a rich and authentic environment. CLIL approach justifies both disequilibrium and opportunities for construction of reality through the techniques of active learning.

\section{Contextualizing CLIL Approach to Journalism Pedagogic Approach}

CLIL is an advanced approach of CLT sharing the similar methodology of teaching. Sometimes it is defended as an alternative to CLT (Coyle et al., 2010) and sometimes as an extension of it (Dalton-Puffer, 2007; Lasagabaster \& Sierra, 2010). Either way, CLIL shares many aspects of CLT, while emphasizing academic content as the substance of the communication, which makes it more relevant and purposeful, by fulfilling more immediate needs. The upper edge that makes CLIL as an advanced approach is its authenticity (subject matter not language as input), the immediate real world relevance (Dalton-Puffer, 2002, 2007; Coyle et al., 2010) and contextualized discourse (Dalton-Puffer, 2002; Gajo, 2007; Lorenzo, 2007; Hüttner \& Smit, 2014). This is why Kern (2000) stresses that CLT has by and large succeeded in its "goal of promoting learners' interactive speaking abilities" that is extraordinarily important in academic settings". Furthermore, CLIL enhances students' intellectual horizons, enables them to apply FL language abilities to a range of academic and practical endeavors, centered more on the learner, based more on cross-cultural awareness and critical reflection (Dupuy, 2011).

Before coming to CLIL, any educational approach should provide the opportunity for both language competence and learning subject matter with the use of authentic materials, students' participation, scaffolding of new knowledge on the basis of existing knowledge, interests and experience in an enriching learning environment with constant reflection (Mehisto, Marsh, \& Frigols, 2008; Cendoya \& Di Bin, 2010). CLIL is "an umbrella term covering a dozen or more educational approaches" (Mehisto et al., 2008) containing a series of didactic methodologies. It starts from "bilingualism" and goes up to the most recent "language across the curriculum", connote the more or less immersive use of FL to learn content (Costa \& D'Angelo, 2011). It is a dual-focused educational approach in which an additional language is used for the learning and teaching of 
both content and language (Coyle et al., 2010). The term CLIL was coined in Europe in the 1990s and is often associated with teaching through the medium of English (Dalton-Puffer, Nikula, \& Smit, 2010). In sum, we can say that when a target language is used to teach a non-linguistic content, it is called as CLIL (Marsh, 2002).

CLIL integrates four different but interrelated and contextualized components: content (subject matter), communication (language learning and using), cognition (learning and thinking processes) and culture (developing intercultural understanding and global citizenship). It calls for learners to be "active participants in developing their potential for acquiring knowledge and skills through a process of inquiry and by using complex cognitive processes and means for problem-solving" (Coyle et al., 2010; Dupuy, 2011). In the course of the last three decades and it has crossed its originally European borders and has landed in countries where educational settings and socio-economic conditions are different. CLIL is currently enjoying a surge in popularity across the world. For instance, in many Southeast Asian countries (e.g. Hong Kong, Malaysia, Singapore), serious government attention is given to promoting CLIL through EMI, whereas in many countries in continental Europe, the implementation of CLIL is in full swing (Pérez-Cañado, 2012). In Ethiopian journalism undergraduate pedagogy also, CLIL may successfully be entertained.

In sum, the literature related to CLIL focus indicates that CLIL is a panacea for journalism undergraduate TL focus. No other approach addresses the TL focus as successful as CLIL does for journalism. Hence, it's a right time to contextualize CLIL in Ethiopian context for its focus on intercultural understanding, internationalization, language competence, content mastery, and learning outcomes for journalism undergraduates.

\section{Contextualizing CLIL 4C Framework to Journalism Curriculum}

CLIL has brought forth a fusion of content and language teaching methodologies (Ioannou-Georgiou, 2012) providing a curriculum guideline called the 4Cs framework: Content, Communication, Cognition, and Culture (Figure 2). Content refers to subject matter, communication refers to language learning and language use, cognition refers to thinking processes and culture refers to relevant contextual knowledge (McDougald, 2009; Coyle et al., 2010). In CLIL, the curriculum designer is aware that these four building blocks are interrelated and interdependent (Castillo, 2008) which makes the curriculum content and language integrative (Wolff, 2009; Coyle et al., 2010; Dupuy, 2011).

Content includes objectives to be achieved and selection and gradation of the course materials based on need, interaction, authentic text, learners experience and progression in knowledge. At the heart of the learning process lie successful content or thematic learning and the acquisition of knowledge, skills and 


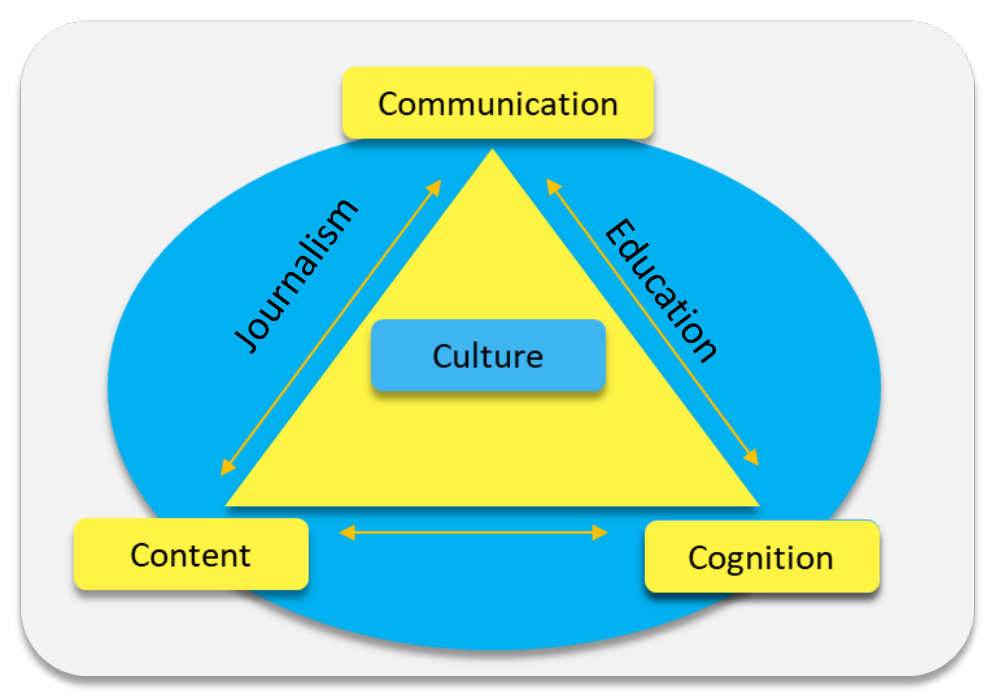

Figure 2. CLIL for journalism curriculum design: Adapted from Coyle et al. (2010).

understanding (Coyle, 2005). Here, in this section of content, the objectives of a particular journalism course will be listed and the course topics will be selected, arranged and graded systematically.

Communication in CLIL is linking content with interaction. What language, do the learners need to work with the content? Providing specialized vocabulary and sentences may help learners in interaction. Language is a conduit for communication and for learning. The formula learning to use language and using language to learn is applicable here (Coyle, 2005). Here, the activities around the theme/topic of a particular journalism course will be preplanned and executed inside the classroom in learners' centered way. Activities in the classroom are platforms of naturalistic communication with the help of learners' experiential inputs and engagements.

Culture in CLIL has wide interpretation depending on the place of its application. Here, the curriculum designer has to search and include the cultural implications of the topic or course under construction. How the topic may bring down to local context (Coyle, 2005). Relevant contextual knowledge is a prerequisite for comprehending the subject content. Learners may compensate a lack of linguistic proficiency by acquiring and applying strategies in the use of contextual cues and in use of relevant background knowledge (Omaggio, 1986). Schema theory suggests that the same text is understood and constructed by different people differently depending on their background knowledge (ibid.).

Cognition in CLIL is to engage learners in thinking skills to construct their own understanding and be challenged in line with Bloom's taxonomy. This leads to the correct way of assessment and testing in CLIL. It shows the way which technique of testing should be appropriate and suitable for what type of content (Coyle, 2005). Tasks should be designed in a way that previous knowledge is activated, and which provides enough background information for the learner to grasp the key concepts (Castillo, 2008). Tasks are catalyst for cognition process 
which develops thinking skills from concept formation (abstract and concrete) to understanding.

Apart from this, a successful CLIL curriculum and program should necessarily be supported by joint effort and involvement of all stakeholders involved, high teacher profile and training, presence of long-term teaching staff, hiring of multilingual and bilingual teachers, high expectations and assessments, use of right materials, respect and support for learner's L1 and native culture (Costa \& D’Angelo, 2011).

In sum, the literature related to CLIL's $4 \mathrm{C}$ framework for curriculum design indicates that CLIL is a panacea for journalism curriculum design. No other approach addresses the curriculum design issue as successful as CLIL does for journalism. Hence, it's a right time to contextualize CLIL in Ethiopian context for its theoretical and philosophical base; proper grading and sequencing; activity and task orientation; process-oriented assessment and culturally and contextually embedded curriculum for journalism undergraduates.

\section{Contextualizing CLIL Design to Journalism Material Development}

When there is a change in teaching approach, there is a modification in material design. This is how the gaps are filled and learning objectives are achieved. The CLIL materials are developed based on the following considerations that it should integrate content, language, and learning skills (Cendoya \& Di Bin, 2010). The subject content should not be complicated, unfamiliar and difficult in acquiring new concepts (Coonan, 2007; Tan, 2011), this might hinder rather than benefit learning and language development. CLIL materials are authentic, well cited and not directly internet searched materials (Castellani, Dabove, \& Colucci, 2009; Banegas, 2011; Ting, 2007; Hunt, 2011). It must be adapted properly. If teachers solely adopt materials without modifying input, there is a chance of misunderstanding. This type of input modification may impinge negatively on the idea that what students are presented should be highly meaningful and functional in terms of both content and language (Banegas, 2011). CLIL materials are context-responsive and locally tailored materials (Castellani et al., 2009; Banegas, 2011; Ting, 2007; Hunt, 2011). It should be semiotic as far as possible because students make meaning of a text by understanding and interpreting the text's set of signs or symbols, which are called semiotic systems: linguistic, visual, auditory, gestural and spatial (Figure 3). Texts are increasingly multimodal, a learner must have mastery of all five semiotic systems and understand how they work together to convey meaning (Anstey \& Bull, 2006; Cendoya \& Di Bin, 2010).

CLIL texts are experiential, that is, designed in a way that learners' previous knowledge is activated. It provides enough background information for the learner to grasp the key concepts in order to expose students to learning material and to genuine contexts of language use (Castillo, 2008; Cendoya \& Di Bin, 2010). The materials are prepared as per the students' interest, need and level 


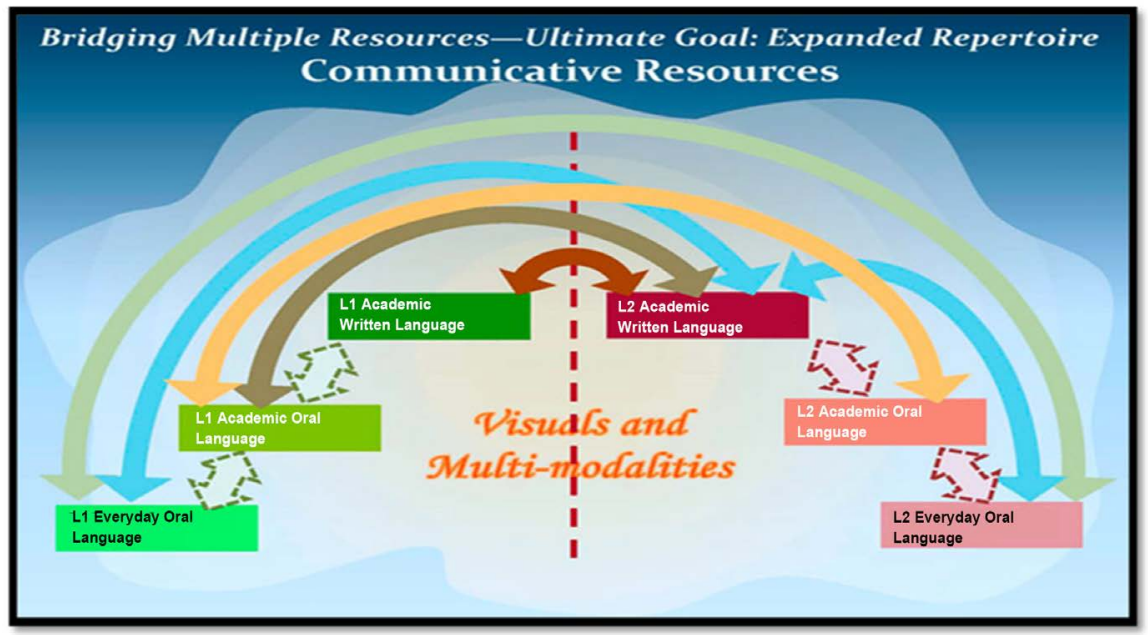

Figure 3. CLIL for journalism material development: Adapted from Lin (2012).

(Castellani et al., 2009; Banegas, 2011; Ting, 2007; Hunt, 2011). Hence, it is better if it is teacher made because the teachers know the real nerve of the learners (Castellani et al., 2009; Banegas 2011; Ting, 2007; Hunt, 2011). The materials should help students develop meta-linguistic awareness and critical thinking (Cendoya \& Di Bin, 2010) and should follow a coherent pattern throughout (Cruz, 2009; Banegas, 2011) to enhance learning. CLIL advocates for subject specific glossary (technical and semi-technical terms) which is often linked to learning the concepts, broadening subject discourse functions and communicative needs (Cendoya \& Di Bin, 2010; Hüttner \& Smit, 2014). Corpus linguistics software is very useful in deciding which words and phrases are frequently appearing in the text based on the number of occurrences (Cardinali et al., 2008; Banegas, 2011). CLIL materials have even "pronunciation points" to correct pronunciations of the learners as it is the local need of learners who have very less exposure to English. Finally, CLIL materials have activities and problem-solving tasks throughout the lesson (Cendoya \& Di Bin, 2010; Hunt, 2011).

To sum up, the literature related to CLIL materials indicates that CLIL is a panacea for journalism material development. No other approach addresses the material development issues as CLIL does for journalism. Hence, it's a right time to contextualize CLIL in Ethiopian context for its adaptable and adoptable; well-ordered and comprehensive; context responsive and locally tailored; interesting and attractive; relevant and updated; and factually rich and informative material development for journalism undergraduates.

\section{Contextualizing CLIL Procedure to Journalism Classroom Practices}

The philosophy of CLIL classroom is social constructivism as it promotes activities to encourage autonomy at a later stage (Banegas, 2011). CLIL classrooms are not typical language classrooms due to the fact that EFL is the medium through which content is transported (Katarzyna, 2012). Marsh \& Langé (2000) describes 
that in CLIL the learning of language and other subjects is mixed in one way or another. This means that in a CLIL class there are two main aims, one related to the subject, topic, or theme and one linked to the language (McDougald, 2009). The learning of academic subject matter contributes to language development (Gajo, 2007). CLIL is characterized by increased communicative interaction (Ting, 2007) focusing on meaning rather than on form, and on fluency rather than on accuracy (Cendoya \& Di Bin, 2010). Harrop (2012) proposes four central features of its classroom: greater linguistic proficiency, motivation, suitability for diverse learners and greater contextual awareness. Although one-language (FL) policy is adhered to by teachers and students even for organization and discipline (Nikula, 2005; Pérez-Vidal, 2009; Banegas, 2011), in CLIL classroom, codes switching between the native and the additional language in teaching is allowed momentarily to clarify the meanings of individual concepts for consolidating the cognitive processes. But, it is important that the teacher should be competent in both the content (without trivializing it) and the language otherwise, he may create confusion, may predispose the student to accept non-acceptable errors, and may favor inaccuracies and superficiality without bringing any real learning advantages to the students (Costa \& D'Angelo, 2011).

Harmer (2007) proposes that one of the teaching procedures which can be used for CLIL classroom is Presentation, Practice and Production (PPP). PPP is a teaching procedure by introducing a contextualized situation. Firstly, the teacher delivers the lecture. Secondly, the students read the study material and lastly, they are given different tasks to accomplish like research and write assignment, read and present, produce wall magazine, posters and/or experiment/report (Prasetianto 2014; Costa \& D’Angelo, 2011). Teachers are key stakeholders in any educational endeavor and among the main agents of educational change (McDougald, 2009). The roles of the CLIL teacher are: to focus on both the linguistic difficulties of the subject matter as well as the subject content itself as per the level to solve the difficulty and need of the learners (Costa \& D'Angelo, 2011); to be well versed at presenting content in the classroom focusing on "accurate form" and "word choices" to present structures, vocabulary, pronunciation and subject cognition (ibid.); to run student-centered and less-teacher-talked lessons devising meaning focused and critical thinking activities and problem-solving tasks (Klimova, 2012; Ting, 2007; Hunt, 2011) to expose students to an appropriately demanding input (by selecting, adapting and scaffolding); to elicit output production; and to help learners acquire compensation strategies in order to facilitate communication (De Graaff, Koopman, Anikina, \& Westhoff, 2007; Costa \& D’Angelo, 2011). According to Klimova (2012), after the lesson teacher should reflect that what skills were manipulated implicitly through the lesson; learning outcomes were achieved or not; what activities were given in the classroom to make the content highly interactive and what problem-solving tasks were given out from the lesson so that students may learn about the world from their own contexts.

CLIL learners are meaning constructors (Kern, 2000; Dupuy, 2011), life-long 
learners having real-world skills (Mackenzie, 2011); academically motivated (Mackenzie, 2011; Munoz, 2007; Spies 2012) and self-confident. They achieve better grades in the content subjects which ease their learning process (Mackenzie, 2011). Language practice is apparently banned from CLIL classroom (Lorenzo, 2007) but a CLIL class includes a variety of different meaning focused and critical thinking activities, which would promote not only essential knowledge of the topic, but also develop student's communicative competence (Klimova, 2012). Important activities are individual projects, presentations, research, experiment, pair work, and group work (Nikula, 2005; Pérez-Vidal, 2009; Banegas, 2011) which help build up both language use and subject concepts. CLIL advocates the cognitively and linguistically challenging problem-solving tasks designed by the teacher as per the theme/topic in the light of objectives to be achieved from the course (Cendoya \& Di Bin, 2010; Hunt, 2011). Through tasks, students unconsciously but naturally master a target language so as to be able to speak effectively.

In sum, the literature related to the nature of CLIL classroom indicates that CLIL is a panacea for journalism classroom practices. No other approach addresses the classroom practices issues as CLIL does for journalism. Hence, it's a right time to contextualize CLIL in Ethiopian context for its focus on attitudinal issues (happiness, confidence, motivation); student-centeredness, activity orientation, task direction, assessment variations, pronunciation enhancement, constructive feedback, and backwash effect in the journalism classroom.

\section{Conclusion}

The need to integrate learning as well as language as a tool of communication is of great importance in today's world. CLIL has emerged as an educational approach to satisfy this need. This approach shares some principles with other methodologies such as task-based and genre-based. Awareness of this close relationship among them is of great significance since it can improve the linguistic competence and the content knowledge in English. A CLIL lesson is a lesson where language is used as a medium to broaden one horizons of knowledge. Students use language to learn about the world around them. It is the topic or task that is a driving force. Nevertheless, one must admit that if a student wants to express his/her ideas on the topic or task clearly and persuasively, she/he has to use the right language. That means that students unconsciously but naturally master a foreign (target) language so as to be able to speak effectively. Moreover, if the right approaches to teaching and learning are used and if the teacher shows his/her enthusiasm, then CLIL must be a success. As Mackenzie (2011) states, CLIL produces life-long learners wherein students are sent out with real-world skills, enhanced motivation, and self-confidence. The need for Ethiopians undergraduates to understand and use English across the curriculum in an undergraduate environment is becoming a requirement. The content that is managed within the field of bilingual education frequently present problems for the students, due to the way in which the content of a given subject matter is taught, 
thereby making language learning more difficult for the students to fully comprehend, thereby leaving a large gap in the teaching-learning cycle. The researcher strongly believes that CLIL is an approach that can be easily adapted to current journalism educational programs in Ethiopia. There is no research conducted on journalism undergraduate pedagogy in Ethiopian contexts. A top-down dissemination of CLIL through curriculum policies and implementations is need of the hour so that ideal journalism TL practices can be established.

This article is limited in a way that promotes the ongoing dialogue on the journalism teaching learning approach in Ethiopia. However, more empirical studies are needed for the critical and comprehensive CLIL contextualization in Ethiopian journalism education in order to better validate the results.

\section{Conflicts of Interest}

The author declares no conflicts of interest regarding the publication of this paper.

\section{References}

Anstey, M., \& Bull, G. (2006). Teaching and Learning Multiliteracies. Newark, NJ: International Reading Association.

Banegas, D. L. (2011). Content and Language Integrated Learning in Argentina 2008-2011. Latin American Journal of Content \& Language Integrated Learning, 4, 33-50. https://doi.org/10.5294/laclil.2011.4.2.4

Berhanu, H. (1999). An Evaluation of the Implementation of the Current ELT Syllabus for Grade 9 in Terms of the CLT Methodology. Master's Dissertation, Addis Ababa: Addis Ababa University. Achieving Communicative Effectiveness? Journal of Pragmatics, 43, 950-964.

Bolton, K., \& Kuttiva, M. (2012). English as an Academic Language at a Swedish University: Parallel Language Use and the "Threat" of English. Journal of Multilingual and Multicultural Development, 33, 429-447. https://doi.org/10.1080/01434632.2012.670241

Bruton, A. (2013). CLIL: Some of the Reasons Why and Why Not. System, 41, 587-597. https://doi.org/10.1016/j.system.2013.07.001

Cañado, M. L. P. (2010). Globalisation in Foreign Language Teaching: Establishing Transatlantic Links in Higher Education. Higher Education Quarterly, 64, 392-412. https://doi.org/10.1111/j.1468-2273.2010.00451.x

Cardinali, R., Di Nardo, E., \& Depetris, S. (2008). Applying Corpus Linguistics Methodology to an ESP Lexico-Grammatical Compendium. In D. Fernández (Ed.), Using the Language to Learn and Learning to Use the Language: What's Next in Latin America. XXXIII FAAPI Conference Proceedings. Santiago del Estero: FAAPI.

Castellani, E., Dabove, C., \& Colucci, L. (2009). Teaching EFL or Teaching Art? In D. Fernández (Ed.), XXXIV FAAPI Conference Proceedings: Teachers in Action. Making the Latest Trends Work in the Classroom. Bahía Blanca: FAAPI.

Castillo, R. (2008). Issues Involved in Context, Comprehension and Content. Latin American Journal of Content and Language Integrated Learning, 1, 15-25. https://doi.org/10.5294/laclil.2008.1.1.2

Cendoya, A. M., \& Di Bin, M. V. (2010). A CLIL Experience Based on the Use of Tasks 
and Different Genre Types. Latin American Journal of Content \& Language Integrated Learning, 3, 11-17. https://doi.org/10.5294/laclil.2010.3.1.2

Claudiocol (2010). CLIL Principle. http://www.teachingenglish.org.uk/blogs/claudiocol/clil-principles

Coonan, C. M. (2007). Insider Views of the CLIL Class through Teacher Self-Observation-Introspection. The International Journal of Bilingual Education and Bilingualism, 10, 625-646. https://doi.org/10.2167/beb463.0

Costa, F., \& Coleman, J. (2010). Integrating Content and Language in Higher Education in Italy. Ongoing Research. International CLIL Research Journal, 1, 19-29.

Costa, F., \& D’Angelo, L. (2011). CLIL: A Suit for All Seasons? Latin American Journal of Content \& Language Integrated Learning, 4, 1-13.

https://doi.org/10.5294/laclil.2011.4.1.1

Coyle, D. (2005). Developing CLIL: Towards a Theory of Practice. APAC Monographs, 6, 5-29.

Coyle, D., Hood, P., \& Marsh, D. (2010). CLIL: Content and Language Integrated Learning. Cambridge: Cambridge University Press.

Cruz, E. (2009). From Understanding CLIL to Profiting from It in Our Classroom. In D. Fernández (Ed.), XXXIV FAAPI Conference Proceedings: Teachers in Action. Making the Latest Trends Work in the Classroom. Bahía Blanca: FAAPI.

Cummins, J. (1984). Bilingualism and Special Education: Issues in assessment and pedagogy. Clevedon, Avon: Multilingual Matters.

Dafouz-Milne, E., \& Sanchez-García, D. (2013). “Does Everybody Understand?” Teacher Questions across Disciplines in English-Mediated University Lectures: An Exploratory Study. Language Value, 5, 129-151. https://doi.org/10.6035/LanguageV.2013.5.7

Dalton-Puffer, C. (2002). Content and Language Integrated Learning in Austrian Schools: Applied Linguistics Takes a Look. Views, 11, 4-26.

Dalton-Puffer, C. (2007). Discourse in Content-and-Language-Integrated Learning (CLIL) Classrooms. Amsterdam: John Benjamins. https://doi.org/10.1075/1llt.20

Dalton-Puffer, C., Nikula, T., \& Smit, U. (2010). Charting Policies, Premises and Research on Content and Language Integrated Learning. In Language Use and Language Learning in CLIL Classrooms (pp. 1-19). Amsterdam: John Benjamins. https://doi.org/10.1075/aals.7.01dal

Davis, K. (1995). Qualitative Theory and Methods in Applied Linguistic Research. TESOL Quarterly, 29, 427-454. https://doi.org/10.2307/3588070

De Graaff, R., Koopman, G. J., Anikina, Y., \& Westhoff, G. (2007). An Observation Tool for Effective L2 Pedagogy in Content and Language Integrated Learning (CLIL). International Journal of Bilingual Education and Bilingualism, 10, 603-624. https://doi.org/10.2167/beb462.0

Doughty, C. J., \& Long, M. H. (2003). The Handbook of Second Language Acquisition. Malden, MA: Blackwell Publishing. https://doi.org/10.1002/9780470756492

Dupuy, B. (2011). CLIL: Achieving Its Goals through a Multiliteracies Framework. Latin American Journal of Content \& Language Integrated Learning, 4, 21-32. https://doi.org/10.5294/laclil.2011.4.2.3

Fernández, D. J. (2009). CLIL at the University Level: Relating Language Teaching with and through Content Teaching. Latin American Journal of Content \& Language Integrated Learning, 2, 10-26. https://doi.org/10.5294/laclil.2009.2.2.11

Fortanet-Gómez, I. (2013). CLIL in Higher Education: Towards a Multilingual Language Policy. Bristol: Channel View. https://doi.org/10.21832/9781847699374 
Gajo, L. (2007). Linguistic Knowledge and Subject Knowledge: How Does Bilingualism Contribute to Subject Development? International Journal of Bilingual Education and Bilingualism, 10, 563-581. https://doi.org/10.2167/beb460.0

Gefall, C. (2009). Empirical and Theoretical Perspectives on Language Learning in CLIL: Delineating Opportunities and Limitations. Master's Dissertation, Wein: Universitat Wein.

Grabe, W., \& Stoller, F. (1997). Content-Based Instruction: Research Foundations, In M. Snow, \& D. Brinton (Eds.), The Content-Based Classroom. Perspectives on Integrating Language and Content (pp. 5-21). New York: Longman.

Graddol, D. (2006). English Next: Why Global English May Mean the End of "English as a Foreign Language. "London: The British Council.

Hailom, B. (1982). English Conditional Sentences: A Comparative Analysis of Structural and Communicative Approach in Teaching to Non-Native Speakers. Master's Dissertation, Addis Ababa: Addis Ababa University.

Harrop, E. (2012). Content and Language Integrated Learning (CLIL): Limitations and Possibilities. Encuentro, 21, 57-70.

Hatch, E. (1992). Discourse and Language Education. Cambridge: Cambridge University Press.

Hunt, M. (2011). UK Teachers' and Learners' Experiences of CLIL Resulting from the EU-Funded Project ECLILT. Latin American Journal of Content \& Language Integrated Learning, 4, 27-39. https://doi.org/10.5294/laclil.2011.4.1.3

Hüttner, J., \& Smit, U. (2014). CLIL: The Bigger Picture. A Response to: A. Bruton. 2013. CLIL: Some of the Reasons Why and Why Not, System, 41 (2013): 587-597. System, 44, 160-167. https://doi.org/10.1016/j.system.2014.03.001

Ioannou-Georgiou, S. (2012). Reviewing the Puzzle of CLIL. ELT Journal, 66, 495-504. https://doi.org/10.1093/elt/ccs047

IMS Assessment Report. Ethiopia in Transition: Hope amid Challenges. (2018). https://www.mediasupport.org/wp-content/uploads/2018/11/Ethiopia.final_.spread.pdf

Jarvinen, H. (2008). Issues in Promoting Language and Learning in CLIL Type Provision. http://lici.utu.fi/materials/article_jarvinen.pdf

Katarzyna, P. (2012). The Impact of Students' Attitude on CLIL: A Study Conducted in Higher Education. Latin American Journal of Content and Language Integrated Learning, 5, 28-56. https://doi.org/10.5294/laclil.2012.5.2.10

Kern, R. (2000). Literacy and Language Teaching. Oxford: Oxford University Press.

Khan, S., \& Pinyana, A. (2014). A Review of Second Language Acquisition Research in CLIL Contexts in European Higher Education. Barcelona: HEPCLIL Conference, Central University of Catalonia.

Kiely, R. (2009). The Question of Assessment. https://www.developingteachers.com

Klimova, B. F. (2012). CLIL and the Teaching of Foreign Languages. Procedia-Social and Behavioral Sciences, 47, 572-576. https://doi.org/10.1016/j.sbspro.2012.06.698

Krashen, S. (1982). Principles and Practice in Second Language Acquisition. Oxford: Pergamon.

Krashen, S., \& Biber, D. (1988). On Course: Bilingual Education's Success in California. Sacramento, CA: California Association for Bilingual Education.

Lakachew, M. (2003). Teachers Attitude towards CLT and Practical Problems in Its Implementation. Master's Dissertation, Addis Ababa: Addis Ababa University.

Lasagabaster, D., \& de Zarobe, Y. R. (2010). CLIL in Spain: Implementation, Results and 
Teacher Training. Newcastle: Cambridge Scholars.

Lasagabaster, D., \& Sierra, J. M. (2010). Immersion and CLIL in English: More Differences than Similarities. ELT Journal, 64, 367-375. https://doi.org/10.1093/elt/ccp082

Lin, A. M. Y. (2012). Multilingual and Multimodal Resources in Genre-Based Pedagogical Approaches to L2 English Content Classrooms, In C. Leung, \& B. V. Street (Eds.), English-A Changing Medium for Education (pp. 79-103). Bristol: Multilingual Matters. https://doi.org/10.21832/9781847697721-007

Long, M. H. (1983). Native/Non-Native Speaker Conversation and the Negotiation of Comprehensible Input. Applied Linguistics, 4, 126-141.

https://doi.org/10.1093/applin/4.2.126

Lorenzo, F. (2007). The Sociolinguistics of CLIL: Language Planning and Language Change in 21st Century Europe. Revista española de lingüística aplicada, 1, 27-38.

Lucietto, S. (2008). A Model for Quality CLIL Provision. International CLIL Research Journal, 1, 83-92.

Mackenzie, A. (2011). How Should CLIL Work in Practice? http://www.onestopenglish.com/support/methodology/teaching-approaches/how-shou ld-clil-work-in-practice/156531.article

Mardziah-Hayati, A. (1998). Problem-Based Learning in Language Instruction: A Constructivist Method. ERIC.

http://www.indiana.edu/ reading/ieo/digests/d132.html

Marsh, D. (2002). CLIL/EMILE-The European Dimension: Actions, Trends and Foresight Potential. Brussels: European Commission.

Marsh, D., \& Langé, G. (2000). Using Languages to Learn and Learning to Use Languages. Jyväskylä \& Milan: TIE-CLIL. http://clilcompendium.com/1uk.pdf

Massler, U., Stotz, D., \& Queisser, C. (2014). Assessment Instruments for Primary CLIL: The Conceptualization and Evaluation of Test Tasks. The Language Learning Journal, 42, 137-150. https://doi.org/10.1080/09571736.2014.891371

McDougald, J. S. (2009). The State of Language and Content Instruction in Colombia. Latin American Journal of Content \& Language Integrated Learning, 2, 44-48. https://doi.org/10.5294/laclil.2009.2.2.15

Mehisto, P., Marsh, D., \& Frigols, M. J. (2008). Uncovering CLIL: Content and Language Integrated Learning in Bilingual and Multilingual Education. Oxford: Macmillan Education.

Munoz, C. (2007). CLIL: Some thoughts on Its Psycholinguistic Principles (pp. 17-26). Revista Espanola de Linguistica Aplicada: Volumen monográfico.

Navés, T., \& Victori, M. (2010). CLIL in Catalonia: An Overview of Research Studies (pp. 30-54).

Nikula, T., \& Järvinen, H. M. (2012). CLIL in Finland. In L. Tainio, \& H. Harju-Luukkanen (Eds.), Bilingual School-The Multilingual Finland of the Future (pp. 143-167). Helsinki: Suomen Kasvatustieteellinen Seura.

Nikula, T. (2005). English as an Object and Tool of Study in Classrooms: Interactional Effects and Pragmatic Implication. Linguistics and Education, 16, 27-58.

https://doi.org/10.1016/j.linged.2005.10.001

Omaggio, A. (1986). Teaching Language in Context: Proficiency-Oriented Instruction. Boston, MA: Heinle \& Heinle.

Overmann, M. (2002). Theoretische Reflexion: Konstruktivistische Prinzipiender Lerntheorie und ihre didaktischen Implikationen (pp. 27-54). 
http://www.ph-ludwigsburg.de/html/2b-frnz-s-01/overmann/baf5/MultimedialeFremd sprachendidaktik27-54.doc

Pérez-Cañado, M. (2012). CLIL Research in Europe: Past, Present, and Future. International Journal of Bilingual Education, 2, 37-41.

Pérez-Vidal, C. (2009). The Integration of Content and Language in the Classroom: A European Approach to Education. In E. Dafouz, \& M. Guerrini (Eds.), CLIL across Educational Levels. London: Richmond.

Pica, T. (1994). Research on Negotiation: What Does It Reveal about Second language Acquisition? Conditions, Processes, and Outcomes. Language Learning, 44, 493-527. https://doi.org/10.1111/j.1467-1770.1994.tb01115.x

Platt, E., \& Frank, B. B. (2002). Task Engagement: A Turning Point in Foreign Language Development. Language Learning, 52, 365-400. https://doi.org/10.1111/0023-8333.00187

Prasetianto, M. (2014). Language Circle. Journal of Language and Literature, 8, 151-162.

Rüschoff, B. (1999). Construction of Knowledge as the Basis of Foreign Language Learning. In B. Mißler, \& U. Multhaup (Eds.), The Construction of Knowledge, Learner Autonomy and Related Issues in Foreign Language Learning: Essays in Honor of Dieter Wolff (pp. 79-88). Tübingen: Stauffenburg Verlag.

Saarinen, T. (2012). Internationalization of Finnish Higher Education-Is Language an Issue? International Journal of the Sociology of Language, 216, 157-173.

https://doi.org/10.1515/ijsl-2012-0044

Shoebottom, P. (2000). The Language Learning Theories of Professor J. Cummins. http://esl.fis.edu/teachers/support/jcummins.html

Smit, U \& Dafouz, E. (2012). Integrating Content and Language in Higher Education. Gaining Insights into English-Medium Instruction at European Universities (Vol. 25). AILA Review. https://doi.org/10.1075/aila.25

Smit, U. (2010a). English as a Lingua Franca in Higher Education. A Longitudinal Study of Classroom Discourse. Berlin: Mouton de Gruyter. https://doi.org/10.1515/9783110215519

Smit, U. (2010b). CLIL in English as a Lingua Franca (ELF) Classroom: On Explaining Terms and Expressions Interactively. In C. Dalton-Puffer, T. Nikula, \& U. Smit (Eds.), Language Use and Language Learning in CLIL Classrooms (pp. 232-250). Amsterdam: John Benjamins. https://doi.org/10.1075/aals.7.13smi

Spies, K. (2012). Intercultural Studies within a CLIL Approach. Latin American Journal of Content \& Language Integrated Learning, 5, 33-45. https://doi.org/10.5294/laclil.2012.5.1.3

Strohner, H. (1995). Cognitive System: Eine Einfuhrung in die Kognitionswissenschaft. Opladen: Westdeutscher Verlag.

Swain, M. (1985). Communicative Competence: Some Roles of Comprehensible Input and Comprehensible Output in Its Development. In S. Gass, \& C. Madden (Eds.), Input in Second Language Acquisition (pp. 235-253). Rowley, MA: Newbury House.

Swain, M. (1993). The Output Hypothesis: Just Speaking and Writing Aren't Enough. The Canadian Modern Language Review, 50, 158-164.

https://doi.org/10.3138/cmlr.50.1.158

Tan, M. (2011). Mathematics and Science Teachers' Beliefs and Practices Regarding the Teaching of Language in Content Learning. Language Teaching Research, 15, 325-342. https://doi.org/10.1177/1362168811401153

Ting, Y. L. T. (2007). A Collective End-of-Symposium Reflection: The State of the Art of 
CLIL and Future Prospects. AILA CLIL-Research Network Symposium. http://www.ichm.org/clil/pdfs/summary_symposium07.pdf

Universities and Colleges in Ethiopia (2018) https://www.examresultethiopia.com/universities-and-colleges/

Wadsworth, B. (1996). Piaget's Theory of Cognitive and Affective Development: Foundations of Constructivism. New York: Longman.

Wagner, S. (1990). BICS, CALP and CUP: Second Language Proficiency and Learning Theory. Teacher Today, IER, 5. http://www.thecenterlibrary.org/cwis/cwisdocs/bics.html

Wendt, M. (1996). Konstruktivistische Fremdsprachendidaktik: Lerner-und handlungsorientierter Fremdsprachenunterricht aus neuer Sicht. Tübingen: Gunter Narr Verlag.

Williams, G., Strubell, M., \& Williams, G. O. (2013). Trends in European Language Education. The Language Learning, 41, 5-36. https://doi.org/10.1080/09571736.2011.567355

Wolff, D. (2007). Eine Fremdsprache als Arbeitssprache gebrauchen: Bilingualer Sachfachunterricht und deutschsprachiger Fachunterricht (pp. 1-58).

Wolff, D. (2009). Content and Language Integrated Learning. In K. Knapp, B. Seidlhofer, \& H. Widdowson (Eds.), Handbook of Foreign Language Communication and Learning (pp. 545-572). Berlin: Walter de Gruyter.

Yemene, D. (2007). English Teachers' Perception and Practice of CLT in the Teachings of English as a Foreign Language. Master's Dissertation, Addis Ababa: Addis Ababa University.

Yonas, A. (2003). Primary School Teachers' Perceive Difficulties in Implementing Innovative ELT Methodologies in Ethiopian Context. IER Flambeau, 11, 23-55. 